\title{
TINJAUAN ATAS PELAKSANAAN PEMUNGUTAN PAJAK HOTEL PADA DINAS PENDAPATAN DAERAH KOTA BOGOR
}

\author{
DEBY SEBA SUSANTI \\ H. EDISON \\ YAYUK NURJANAH
}

ABSTRAK

Pajak daerah merupakan suatu bentuk peran serta masyarakat dalam penyelenggaraan otonomi daerah. Pajak daerah yaitu sumber pendapatan yang dikelola pemerintah daerah yang hasilnya dipergunakan untuk membiayai pengeluaran rutin dan pembangunan daerah. Berdasarkan Undang-undang No. 28 Tahun 2009 tentang perubahan atas UU No. 34 tahun 2004 tentang pajak daerah, dikatakan bahwa pajak daerah yang dapat dipungut oleh daerah berupa Pajak Hotel; Pajak Restoran; Pajak Hiburan; Pajak Reklame; Pajak Penerangan Jalan; Pajak Parkir; Pajak Air Tanah.

Tujuan dari praktek kerja ini adalah untuk mengetahui dasar pengenaan pokok pajak, mengetahui bagaimana pelaksanaan pemungutan, pembayaran, perhitungan pajak hotel serta untuk mengetahui seberapa besar kesadaran masyarakat dalam melaksanakan pembayaran pajak demi meningkatkan pendapatan daerah dan untuk kesejahteraan bersama pada Dinas Pendapatan Daerah Kota Bogor.

Hasil evaluasi dalam praktek kerja lapangan ini, menunjukan bahwa pada Dinas Pendapatan Daerah merupakan suatu unsur pelaksana pemerintah daerah yang mempunyai tugas membantu bupati atau walikota untuk melaksanakan kewenangan pemerintah daerah dibidang pendapatan daerah dalam rangka pelaksanaan tugas desentralisasi dan pembantuan. Dari semua penjelasan yg ada penulis menyimpulkan bahwa pada Dinas Pendapatan Daerah Kota Bogor dalam melakukan pekerjaanya berjalan dengan baik, dilihat dari segi tata kerja terutama dalam proses pelaksanaan pajak daerah yaitu pajak hotel semuanya berjalan sesuai dengan peraturan daerah yang berlaku, dari proses pengenaan pajak, besarnya pokok pajak, proses dalam melaksanakan pemungutan, pembayaran, penghitungan sampai penagihan pajak semua sesuai dengan peraturan daerah yang berlaku.

Kata Kunci : Pajak, Pajak Daerah, Pendapatan Daerah. 


\section{BAB I \\ PENDAHULUAN}

\subsection{Latar Belakang Masalah}

Keuangan negara dan pembangunan nasional tidak dapat dipisahkan dari keuangan daerah dan pembangunan daerah, bahkan dapat dikatakan pembangunan nasional identik dengan pembangunan daerah, karena pembangunan itu sendiri pada dasarnya dilaksanakan di daerah. Oleh karena itu perlu dilaksanakan penyerahan serta pengolahan dana pembangunan secara efektif dan efisien. Sejalan dengan pengolahan keuangan negara, berbagai kebijakan yang telah ditempuh selalu diarahkan agar pembangunan di daerah dapat lebih meningkatkan pertumbuhan ekonomi daerah dan sekaligus meningkatkan perekonomian nasional.

Tujuan pembangunan nasional bangsa Indonesia adalah untuk mencapai masyarakat yang adil, makmur, dan merata baik secara material maupun spiritual. Untuk mewujudkan suatu pembangunan yang dicita-citakan, diperlukan sarana dan prasarana yang dapat berupa sumber daya manusia, pengetahuan dan tekhnologi, situasi politik yang mendukung dan dana yang memadai. Dalam rangka memenuhi kebutuhan dana yang memadai guna pembangunan nasional, pemerintah mempunyai sumber-sumber penerimaan yang berasal dari luar negeri dan dalam negeri. Salah satu contoh penerimaan pemerintahan yang berasal dari dalam negeri yang sangat potensial sekali untuk membiayai pembangunan nasional adalah dari sektor pajak.

Pajak merupakan salah satu sumber penerimaan Negara yang digunakan untuk melaksanakan pembangunan bagi seluruh rakyat Indonesia. Pajak dipungut dari warga Negara Indonesia dan menjadi salah satu kewajiban yang dapat dipaksakan penagihannya. Pembangunan nasional Indonesia pada dasarnya dilakukan oleh masyarakat bersamasama pemerintah. Oleh karena itu peran masyarakat dalam pembiayaan pembangunan harus terus ditumbuhkan dengan meningkatkan kesadaran masyarakat tentang kewajibannya membayar pajak. 
Pajak merupakan alternatif yang sangat potensial. Sebagai salah satu sumber penerimaan Negara yang sangat potensial, sektor pajak merupakan pilihan yang sangat tepat, selain karena jumlahnya yang relatif stabil juga merupakan cerminan partisipasi aktif masyarakat dalam membiayai pembangunan. Jenis pungutan di Indonesia terdiri dari pajak Negara (pajak pusat), pajak daerah, retribusi daerah, bea dan cukai dan penerimaan Negara bukan pajak. Salah satu pos Penerimaan Asli Daerah (PAD) dalam anggaran pendapatan belanja daerah (APBD) adalah pajak daerah.

Salah satu sumber dana yang berupa pajak yang dimaksud adalah pajak hotel. Pajak hotel dapat dimanfaatkan untuk berbagai fungsi penentuan kebijakan yang terkait dengan Pendapatan Asli Daerah (PAD). Meskipun penerimaan pajak hotel memberikan kontribusi terhadap penerimaan pajak yang relatif kecil, namun pajak hotel merupakan sumber penerimaan yang potensial bagi daerah. Sebagai salah satu pajak tidak langsung pajak hotel merupakan pajak daerah karena dipungut oleh Pemerintah Daerah dan digunakan untuk membiayai rumah tangga daerah. Dan semakin meningkatnya jumlah hotel di Kota Bogor, maka memungkinkan dilaksanakannya pemungutan pajak hotel oleh Pemerintah Daerah Kota Bogor.

Pajak hotel sebagai salah satu penerimaan asli daerah, maka Pemerintah Daerah Kota bogor harus berusaha mengoptimalkan penerimaan pajak daerah yang telah ditetapkan dan untuk meningkatkan pendapatan asli daerah yang digunakan untuk membiayai urusan rumah tangganya sendiri. Berdasarkan uraian diatas, penulis merealisasikannya dalam penulisan tugas akhir ini dengan judul "Tinjauan Atas Pelaksanaan Pemungutan Pajak Hotel Pada Dinas Pendapatan Daerah Kota Bogor”

\subsection{Identifikasi Masalah}

Berdasarkan judul dan latar belakang yang telah dikemukakan diatas, maka penulis mengidentifikasikan masalah sebagai berikut :

1. Bagaimana prosedur pemungutan pajak hotel?

2. Kendala apa saja yang dihadapi dalam pemungutan pajak hotel? 
3. Strategi apa yang diterapkan untuk meningkatkan penerimaan pajak hotel?

\subsection{Maksud dan Tujuan}

\subsubsection{Maksud}

Maksud dan penelitian yang dilakukan oleh penulis adalah untuk memperoleh informasi dari Dinas Pendapatan Daerah Kota Bogor tentang prosedur pemungutan pajak hotel yang dilakukan Pemerintah Daerah Kota bogor.

\subsubsection{Tujuan}

1. Untuk mengetahui bagaimana prosedur pemungutan pajak hotel?

2. Untuk mengetahui kendala apa saja yang dihadapi dalam pemungutan pajak hotel?

3. Untuk mengetahui strategi apa yang diterapkan untuk meningkatkan penerimaan pajak hotel?

\subsection{Waktu dan Tempat Magang}

Dalam melakukan kegiatan magang penulis mendapatkan kesempatan peninjauan yang dilaksanakan pada Dinas Pendapatan Daerah Kota Bogor. Yang berlokasi di Jalan Pemuda No. 31 Tanah Sereal Bogor. Waktu pelaksanaan magang penulis lakukan selama dua bulan (7 minggu). 


\section{BAB IV}

\section{KESIMPULAN DAN SARAN}

\subsection{Kesimpulan}

1. Dalam prosedur pemungutan pajak hotel wajib pajak diwajibkan untuk melaporkan usahanya serta wajib untuk menghitung, memperhitungkan, dan melaporkan sendiri pajak yang terutang dengan menggunakan SPTPD atau dokumen lain yang dipersamakan. SPTPD yang diterima akan dilakukan penelitian dan dari hasil penelitian akan diterbitkan SKPD (SKPDKB, SKPDKBT, dan SKPDN). Pembayaran pajak terutang dilaksanakan paling lambat 15 (lima belas) hari setelah berakhirnya masa pajak dan dilakukan pada Kas Umum Daerah atau Bank Jabar atau tempat lain yang ditunjuk oleh Walikota. Wajib pajak yang belum melaksanakan pembayaran pajak terutang, dilakukan penagihan setelah melewati jatuh tempo dengan menggunakan Surat Tagihan Pajak Daerah (STPD) atau dokumen lain yang di persamakan sesuai dengan ketentuan peraturan perundangundangan.

2. Dalam hal pemungutan juga ditemukan beberapa kendala, seperti tingkat kesadaran wajib pajak yang masih rendah dalam memenuhi kewajibannya membayar pajak, serta kecurangan pajak yang dilakukan oleh wajib pajak dalam menghitung dan membayar pajak dengan cara menggunakan faktur palsu dan merendahsajikan total jumlah pendapatan (omset) yang seharusnya diterima oleh wajib pajak tersebut.

3. Dinas Pendapatan Daerah Kota Bogor dalam hal ini telah melakukan strategi - strategi untuk meningkatkan penerimaan pajak hotel, baik dengan intensifikasi maupun ekstensifikasi yaitu melakukan pendidikan teknis/diklat struktural, mamelakukan pelaksanaan sosialisasi peraturan daerah, mendatangi wajib pajak serta melakukan pemeriksaan terhadap dokumen yang dilampirkan. Agar penerimaan pajak akan lebih optimal.

\subsection{Saran}


Berdasarkan kesimpulan di atas, penulis memberikan saran sebagai berikut:

1. Untuk meningkatkan kesadaran dan pemahaman yang benar dari wajib pajak terhadap pajak dan pelaksanaan pemungutan pajak serta peraturan dan perundang-undangan khususnya yang mengatur pajak hotel hendaknya diadakan program penyuluhan perpajakan secara rutin dan terjadwal karena dengan membayar pajak maka masyarakat turut berkontribusi dalam pembangunan dan peningkatan kesejahteraan masyarakat secara umum.

2. Untuk meningkatkan dan mengoptimalkan penerimaan pajak daerah Dinas Pendapatan daerah Kota Bogor harus melakukan pendataan potensi pajak, melakukan pengawasan terhadap wajib pajak agar dapat mengurangi tingkat kecurangan dalam pemungutan pajak, serta dengan menerapkan aturan perpajakan dengan tegas. 


\section{DAFTAR PUSTAKA}

Ahmad Yani. 2002, Hubungan Keuangan Antara Peerintah Pusat dan Daerah Di Indonesia. Jakarta : PT. Raja Grafindo Persada.

Buku Pedoman Dinas Pendapatan Daerah Kota Bogor

http://dispenda.bogor.go.id/dasar-pengenaan-tarif-perhitungan/

Mardiasmo, 2011. Perpajakan CV Andi Offset. Yogyakarta

Herry Purwono. 2010. Dasar-dasar Perpajakan \& Akuntansi Pajak. Jakarta : PT. Gelora Aksara Utama.

Peraturan Daerah Kota Bogor Nomor 12 Tahun 2011 Nomor 8 Seri B Tentang Pajak Hotel.

Peraturan Daerah Kota Bogor Nomor 21 Tahun 2011 Nomor 9 Seri E Tentang Ketentuan Umum Pajak Daerah.

Undang-undang Republik Indonesia Nomor 28 Tahun 2009 Tentang Pajak Daerah dan Retribusi Daerah.

Profil Dinas Pendapatan Daerah Kota Bogor

DANIAL, M., PENGARUH SISTEM PENGENDALIAN INTERN PENJUALAN TERHADAP EFEKTIVITAS PENJUALAN.

Afriyudi, A. and Sutomo, H., 2013. Perancangan Dan Pembuatan Alat Pengaman Rumah Menggunakan Mikrokontroller At89s52 Dan Telepon Seluler Berbasis J2ME. Proceedings of KNASTIK.

Djanegara, H.M.S., 2004. Evaluasi Atas Pelaksanaan Audit Dalam Meningkatkan Efektifitas Sistem Informasi Persediaan Barang Jadi: Studi Kasus Pada PT. Cahaya Furnindotama. Jurnal IImiah Ranggagading (JIR), 4(2), pp.55-60.

Pamungkas, B., 2005. Pengaruh Kualitas Peraturan Perundang-undangan, Akuntansi Keuangan Sektor Publik, dan Penerapan Pengawasan terhadap Kualitas Laporan Keuangan Pemerintah dan Akuntabilitas Kinerja Instansi Pemerintah. Disertasi UNPAD. Bandung. Tidak Dipublikasikan.

Iriyadi, 1994. The Influence of Participation on the Relation Between Supervisory Evaluative Style and Managerial Performance and Job Satisfaction in Indonesia. University of South Australia..

Iriyadi and Gurd, B., 1998. Cultural effects of budgetary participation: Indonesian evidence. Asian Review of Accounting, 6(2), pp.71-100.

Sutarti, S. and Prayitno, D., 2007. Analisis PSAK No. 45 dalam penyajian Laporan Keuangan Organisasi Nirlaba Studi Kasus pada Rumah Sakit" X". Jurnal IImiah Ranggagading (JIR), 7(1), pp.30-36. 
Haryanti, A., Muktiadji, N. and Setiana, A., 2013. Analisis Dividen Tunai dan Earning Per Share Terhadap Tingkat Imbal Hasil Investor.

Hidayat, L. and Mhaydaly, S., 2008. Analisis Risiko Dan Arus Kas Terhadap IRR: Studi kasus pada PT. Dharmala Intiland Tbk, PT. Duta Pertiwi Tbk dan PT. Kawasan Industri Jababeka Tbk. Jurnal IImiah Ranggagading (JIR), 8(1), pp.51-58.

Supriadi, Y. and Sofyana, A., 2012. Analisis Pengaruh Likuiditas dan Solvabilitas terhadap Rentabilitas pada Koperasi Karyawan PLN Cipta Usaha. Jurnal IImiah Ranggagading (JIR), 12(2), pp.186-192.

Andrayani, I.P. and Nurendah, Y., 2013. PROSEDUR PENJUALAN SEPEDA MOTOR PADA DEALER HONDA PT. SANPRIMA SENTOSA BOGOR. Jurnal Online MahasiswaManajemen, 1 (1).

Meliana, S. and Setiawan, B., 2013. Pengaruh Kualitas Pelayanan dan Kepercayaan Konsumen Terhadap Keputusan Pembelian. IImiah Manajemen Kesatuan, 1, pp.247-254.

Munawar, A., Sanim, B., Manurung, A.H. and Achsani, N.A., 2011. PENGUJIAN PECKING ORDER PADA PERUSAHAAN PERKEBUNAN DI INDONESIA. Jurnal Ilmiah Ranggagading, 11(2). 